IJMS 18 (1), 239-267 (2011)

\title{
INTERAKSI ANTARA KEPUASAN KERJA DENGAN SIKAP TERHADAP WANG SEBAGAI PERAMAL KEPADA KEINGINAN UNTUK BERHENTI KERJA SECARA SUKARELA
}

\author{
AZMAN ISMAIL \\ Faculty of Defence and Management Studies \\ Universiti Pertahanan Nasional Malaysia \\ CINDY JOHN \\ Faculty of Cognitive Science and Human Development \\ Universiti Malaysia Sarawak \\ MOHD NOOR MOHD SHARIFF \\ UUM College of Business \\ Universiti Utara Malaysia \\ MOHD NA'EIM BIN AJIS \\ NOOR FAIZZAH BT DOLLAH \\ UUM College of Law, Government and International Studies \\ Universiti Utara Malaysia
}

\begin{abstract}
Abstrak
Tujuan utama kajian ini dilaksanakan untuk mengukur kesan kepuasan kerja dan sikap terhadap wang ke atas keinginan untuk berhenti kerja secara sukarela. Kaedah soal selidik telah digunakan untuk mengumpul 140 borang soal selidik daripada pekerja yang berkhidmat di sebuah penguasa tempatan bertaraf bandaraya di Sabah, Malaysia. Keputusan analisis regresi hierarki menunjukkan dua dapatan penting: pertama, interaksi di antara kepuasan kerja intrinsik dan sikap terhadap wang mempunyai hubungan yang signifikan dengan keinginan pekerja untuk berhenti kerja. Kedua, interaksi diantara kepuasan kerja ekstrinsik dan sikap terhadap wang mempunyai hubungan yang signifikan dengan keinginan pekerja untuk berhenti kerja secara sukarela. Keputusan ujian statistik ini menunjukkan bahawa sikap positif terhadap wang di kalangan pekerja yang mempunyai kepuasan kerja intrinsik berupaya menghalang hasrat mereka untuk berhenti kerja secara sukarela. Manakala, sikap positif terhadap wang di kalangan pekerja yang mempunyai kepuasan kerja ekstrinsik tidak berupaya menghalang hasrat
\end{abstract}


mereka untuk berhenti kerja secara sukarela. Dapatan kajian mengesahkan bahawa sikap terhadap wang hanya bertindak sebagai pemboleh ubah penyederhana separa dalam model kepuasan kerja dalam organisasi kajian. Selanjutnya, perbincangan dan implikasi kajian turut dihuraikan.

Kata kunci: Kepuasan kerja, sikap terhadap wang, keinginan untuk berhenti kerja secara sukarela.

\begin{abstract}
Purpose - The paper is primarily conducted to quantify the effect of job satisfaction and attitudes toward money on voluntary turnover.

Design/Methodology/Approach - A survey method was used to gather 140 usable questionnaires from employees who have worked in a city based local authority in Sabah, Malaysia.

Findings - Outcomes of hierarchical regression analysis showed two important findings: firstly, interaction between intrinsic job satisfaction and attitudes toward money significantly correlated with voluntary turnover. Secondly, interaction between extrinsic job satisfaction and attitudes toward money significantly correlated with voluntary turnover. These results show that the inclusion of attitudes toward money in the analysis has motivated intrinsic job satisfiers to decrease their intentions to leave organization, but had not motivated extrinsic job satisfiers to decrease their intentions to leave organization.
\end{abstract}

Originality/Value - The paper confirms that attitudes toward money act as a partial moderating variable in the job satisfaction model of the studied organization.

Keywords - Job satisfaction, attitudes toward money, voluntary turnover.

Paper type - Research Paper.

\title{
Pengenalan
}

Kajian berkaitan pembangunan sumber manusia dan gelagat organisasi menegaskan bahawa kepuasan kerja adalah isu yang kritikal (Ismail, Ishak, Kuching \& Omar, 2008; McShane \& Von Glinow, 2005; Udechukwu, 2007; Weiss, 2002). Kepuasan kerja adalah konsep umum yang boleh diteliti daripada dua dimensi utama, iaitu kepuasan kerja intrinsik dan kepuasan kerja ekstrinsik (Golembiewski, 1993;

240 IJMS 18 (1), 239-267 (2011) 
Herzberg, 1968; Hulin \& Smith, 1965; Wernimont, 1966). Kepuasan kerja intrinsik ditakrifkan sebagai perasaan seseorang pekerja terhadap aspek dalaman pekerjaannya seperti sifat kerja, pencapaian, penghargaan, perkembangan dan pertumbuhan individu (Herzberg, 1968; Linz, 2003; McShane \& Von Glinow, 2005; Tang, Tan, Kim \& Tang, 2000, 2002b). Sementara itu, kepuasan kerja ekstrinsik pula merujuk kepada perasaan seseorang pekerja terhadap aspek luaran pekerjaan tersebut seperti polisi organisasi, gaya penyeliaan, bayaran gaji atau upah, hubungan dengan rakan sekerja, suasana tempat kerja, status, jaminan dan keselamatan di tempat kerja (Herzberg, 1968; Kendall, Smith, Hulin \& Locke, 1963; Locke, Smith, Kendall, Hulin \& Miller, 1964; Mobley, 1977, 1982; Spector, 1997).

Para sarjana banyak berpendapat bahawa sekiranya sesuatu pekerjaan dapat diaturkan dengan baik, maka ia berupaya meningkatkan kepuasan kerja intrinsik dan ekstrinsik, dan seterusnya pula boleh mendorong meningkatkan sikap dan tingkah laku positif pekerja, seperti mengurangkan keinginan untuk berhenti kerja secara sukarela (Applebaum, 2008; Ghiselli, La Lopa \& Bani, 2001; Lacity, Lyer \& Rudramuniyaiah; 2008; Park \& Kim, 2009; Vidal, Valle \& Aragon, 2007). Dougherty, Bluedorn \& Keon (1985) dan Mobley $(1977,1982)$ mentakrifkan keinginan untuk berhenti secara sukarela sebagai keputusan seseorang pekerja untuk meninggalkan organisasi atas pilihan sendiri untuk mencari kepuasan di organisasi yang lain. Sungguhpun sifat perhubungan ini adalah penting, namun perbincangan tentang bagaimana kepuasan kerja boleh mempengaruhi keinginan untuk berhenti kerja secara sukarela dalam organisasi yang berlainan kurang diberi penekanan dalam kajian literatur kepuasan kerja (Applebaum, 2008; Sang, Isou \& Dainty, 2009; Park \& Kim, 2009; van Dam, 2008; Tang et al., 2000).

Analisis yang lebih mendalam oleh Judge $(1990,1993)$ dan Tang et al. $(2000,2002 b)$ terhadap perhubungan antara kepuasan kerja dengan keinginan untuk berhenti kerja secara sukarela didapati akan berubah apabila sikap pekerja terhadap wang hadir dalam organisasi. Dalam konteks pengurusan sumber manusia, wang sering dikaitkan dengan gaji dan bonus (Milkovich \& Newman, 2008), manakala sikap terhadap wang pula kerap merujuk kepada penilaian seseorang individu terhadap wang sama ada secara positif atau negatif (Furham \& Okamura, 1999; Hoon \& Lim, 2001; Tang, Luna-Arocas, Sutarso \& Tang, 2004a). Secara umumnya, sikap terhadap wang boleh diteliti daripada tiga perspektif iaitu individu, organisasi dan psikologi. Dalam perspektif individu, Kahneman dan Tversky (1979), Tang (1993), Tang et al. (2002a, 2004a, 2004b) dan Durvasula dan Lysonski (2007) telah merujuk sikap terhadap wang kepada pertimbangan 
atau penilaian peribadi seseorang pekerja terhadap fungsi wang sebagai memberi kebaikan, membawa kemusnahan, penghormatan, menentukan keupayaan untuk berbelanja, dan kebebasan. Dalam konteks organisasi, Milkovich dan Newman (2008) pula merujuk wang kepada sejumlah ganjaran dalam bentuk gaji dan bonus yang diperuntukkan oleh majikan kepada pekerja kerana melaksanakan sesuatu tugas atau perkhidmatan. Sikap terhadap wang daripada perspektif psikologi pula boleh dibahagikan kepada pandangan bersifat positif atau negatif individu terhadap wang. Campion (1991); Tang (2007); dan Tang dan Baumeister (1984) mengaitkan sikap positif terhadap wang sebagai sesuatu yang utama dalam hidup, lambang kejayaan dan kemegahan, dan lebih penting apabila wang dilihat sebagai mengatasi aspek-aspek kehidupan yang lain. Sikap negatif terhadap wang pula dikaitkan dengan sesuatu yang bukan merupakan keutamaan hidup, malah sebaliknya dilihat sebagai sumber keburukan dan malapetaka dalam kehidupan. Dalam konteks ini, menurut Furham (1996) dan Tang (1992), kepuasan kerja adalah lebih penting daripada mengejar jumlah wang yang besar dalam kehidupan.

Kebanyakan sarjana seperti Adams (1963, 1965); Lawler, (1971); dan Opsahl dan Dunnette (1966) berpendapat bahawa kepuasan kerja intrinsik dan ekstrinsik semata-mata tidak berupaya menghalang seseorang pekerja untuk berhenti secara sukarela. Sebaliknya, sesetengah pekerja akan mengambil keputusan untuk berhenti demi mencari kepuasan di organisasi lain sekiranya mereka merasakan bahawa wang yang diperuntukkan oleh majikan adalah tidak memadai untuk memenuhi keinginan dan pengharapan mereka. Pendapat ini turut dipersetujui oleh para sarjana terkemudian seperti Fisher dan Locke (1992), Tang dan Gilbert (1995), dan Tang et al., (2000, 2002a, $2002 b$ ). Mereka mendapati seseorang pekerja yang merasa puas hati terhadap kerjanya tidak akan berhenti untuk mencari kepuasan di organisasi lain sekiranya beliau merasakan bahawa nilai wang yang diperuntukkan oleh pihak majikan mampu memenuhi matlamatnya.

Penemuan-penemuan ini membuktikan bahawa walaupun sifat perhubungan antara kepuasan kerja dan kecenderungan untuk berhenti telah banyak dikaji, namun peranan sikap terhadap wang sebagai pemboleh ubah penyederhana dilihat masih kurang diberi penekanan dalam model-model kepuasan kerja setakat ini (Mobley, 1977, 1982; Spector, 1997; Steers \& Mowday, 1981; Tang et al., 2002, 2002b; Ismail et al., 2008). Kekurangan ini telah mendorong penyelidik untuk mengambil kira peranan sikap terhadap wang sebagai pemboleh ubah penyederhana dalam perhubungan di antara kepuasan kerja dan keinginan untuk berhenti secara sukarela di 
sebuah penguasa tempatan di Sabah. Untuk menjaga nama baik, nama sebenar organisasi ini dirahsiakan. Para sarjana mengatakan bahawa pengabaian sikap terhadap wang sebagai pemboleh ubah penyederhana dalam model-model kepuasan kerja mungkin disebabkan kajian-kajian lepas terlalu banyak menggunakan pendekatan deskriptif bagi menghuraikan konsep-konsep kepuasan kerja, sikap terhadap wang dan keinginan untuk berhenti kerja sukarela secara terpisah-pisah. Selain itu, kajian-kajian lepas juga banyak menggunakan model korelasi bivariat sebagai pendekatan utama bagi menganalisa perkaitan secara langsung antara kepuasan kerja dan keinginan untuk berhenti kerja secara sukarela. Sungguhpun pendekatan korelasi ini dapat menghasilkan dapatan yang signifikan, tetapi sikap individu yang dinamik telah diabaikan dalam mereka bentuk model-model kepuasan kerja. Akibatnya, hasil kajian lepas tidak dapat memandu ahli akademik dan pengurus untuk memahami dengan jelas konsep kepuasan kerja yang bersifat abstrak dan dinamik. Seterusnya, keadaan ini tidak banyak membantu mempermudahkan mereka mencari jalan penyelesaian yang universal bagi mengatasi masalah sikap dan gelagat pekerja di organisasi yang beroperasi dalam pasaran ekonomi global (Ismail et al., 2008; Spector, 1997; Tang, 1992, 1993, 1995).

\section{Objektif Kajian}

Kajian ini mempunyai tiga objektif. Pertama, mengukur perhubungan di antara kepuasan kerja intrinsik dan keinginan untuk berhenti secara sukarela. Kedua, mengukur perhubungan antara kepuasan kerja ekstrinsik dan keinginan untuk berhenti secara sukarela. Ketiga, mengukur peranan sikap terhadap wang sebagai pemboleh ubah penyederhana dalam perhubungan antara kepuasan kerja intrinsik dan keinginan untuk berhenti kerja secara sukarela. Lokasi kajian ialah sebuah penguasa tempatan bertaraf bandaraya di Sabah, Malaysia. Nama sebenar organisasi ini dirahsiakan untuk menjaga nama baik organisasi kajian.

\section{Kajian Literatur}

\section{Kaitan antara Kepuasan Kerja dan Keinginan untuk Berhenti Kerja Secara Sukarela}

Kebanyakan kajian lepas telah dikendali berdasarkan model kesan langsung bagi mengkaji kepuasan kerja intrinsik dengan menggunakan sampel yang berbeza, seperti 522 pekerja di 50 
agensi insuran hayat (Schneider \& Snyder, 1975), 155 pekerja dari 40 agensi di Selatan Amerika Syarikat (Tang et al., 2000), 81 pengurus temuduga dengan 25 pekerja profesional teknologi maklumat berbangsa India (Lacity et al., 2008), dan 81 pengurus berbangsa Sepanyol yang dihantar pulang ke negara asal (Vidal et al., 2007), 556 kumpulan pekerja yang berpotensi untuk berhenti kerja (van Dam, 2008), 116 jururawat berdaftar sepenuh masa yang bertugas di bahagian perubatan hospital (Applebaum, 2008). Dapatan kajian ini menunjukan bahawa pekerja yang merasa puas hati terhadap ciri-ciri kerja intrinsik (seperti kandungan tugas, kesesuaian sifat kerja, peralihan kerja, penugasan kerja, dan tekanan beban tugas) mempunyai keinginan yang kurang untuk berhenti kerja secara sukarela. Oleh itu, hipotesis yang akan diuji ialah:

H1: Terdapat hubungan yang signifikan di antara kepuasan kerja intrinsik dan keinginan untuk berhenti kerja secara sukarela.

Kajian-kajian lepas berdasarkan model kesan langsung telah digunakan untuk mengkaji kepuasan kerja ekstrinsik dengan menggunakan sampel yang berbeza, seperti 373 pekerja perkhidmatan makanan di rangkaian hotel-hotel kelas pertama di Hong Kong (Mok \& Finley, 1986), 400 pengurus di lapan buah syarikat perkhidmatan makanan kepunyaan Amerika Syarikat (Ghiselli et al., 2001), 527 jururawat yang bekerja di dua hospital awam Korea (Park \& Kim, 2009), dan 110 orang arkitek di United Kingdom (Sang et al., 2009). Dapatan kajian ini menunjukkan bahawa pekerja yang merasa puas dengan ciri-ciri kerja ekstrinsik (budaya kerja, polisi dan prosedur kerja, gaya penyeliaan, persekitaran tempat kerja, hubungan dengan teman dan ganjaran kerja) mempunyai keinginan yang kurang untuk berhenti kerja secara sukarela. Oleh itu, hipotesis yang akan diuji ialah:

H2: Terdapat hubungan yang signifikan di antara kepuasan kerja ekstrinsik dan keinginan untuk berhenti kerja secara sukarela.

\section{Kaitan antara Kepuasan Kerja, Sikap Terhadap Wang dan Keinginan untuk Berhenti Kerja Secara Sukarela}

Beberapa kajian yang dilaksanakan baru-baru ini telah menggunakan model kesan tak langsung bagi mengkaji kepuasan kerja dan hasil kajian ini menunjukan bahawa sejauh mana besarnya kesan kepuasan kerja intrinsik dan ekstrinsik ke atas keinginan pekerja untuk berhenti kerja secara sukarela (Ghiselli et al., 2001; Park \& Kim, 2009; Shields \& Ward, 2001; Vidal et al., 2007) adalah dipengaruhi oleh sikap pekerja terhadap wang (Currall, Towler, Judge \& Kohn, 2005; DeConinck 
\& Bachmann, 2005; Ismail et al., 2008; Randolph \& Johnson, 2005; Tang et al., 2000, 2002a). Sebagai contoh, Tang et al. (2000) mengkaji kepuasan kerja intrinsik berdasarkan sampel 155 pekerja dari 40 agensi di Selatan Amerika Syarikat. Mereka mendapati bahawa faktor kepuasan kerja intrinsik mampu mengurangkan keinginan untuk berhenti kerja secara sukarela dalam keadaan di mana pekerja merasakan bahawa jumlah wang diperuntukkan oleh majikan adalah mencapai kehendak dan pengharapan mereka. Manakala, Ismail et al. (2008) mengkaji kepuasan kerja ekstrinsik berdasarkan sampel 93 pekerja di penguasa tempatan berstatus bandaraya di Sarawak, Malaysia. Kajian ini mendapati bahawa faktor kepuasan kerja ekstrinsik berupaya mengurangkan keinginan untuk berhenti kerja secara sukarela dalam situasi yang pekerja merasakan bahawa jumlah wang yang diperuntukkan oleh majikan mencapai kehendak dan pengharapan mereka.

Bukti empirik di atas adalah konsisten dengan saranan-saranan daripada teori gelagat organisasi, iaitu model sikap ABC (Ajzen \& Fishbein, 1977), teori ekuiti (Adams, 1963, 1965), dan model diskrepensi (Lawler, 1971). Dalam model sikap ABC oleh Ajzen dan Fishbein (1977), wang sebagai komponen afektif dilihat bukan sebagai sumber kejahatan, tetapi wang sebagai komponen kognitif dianggap sebagai simbol kejayaan. Sebagai komponen gelagat pula, wang diamati dari segi perbelanjaan yang berhemat. Individu yang mempunyai pandangan sedemikian terhadap wang kebiasaannya lebih menjunjung tinggi nilai ekonomi, rendah nilai keagamaan, berminat kepada politik dan sering merasa tidak puas hati terhadap tahap ganjaran yang diperoleh (Tang, 2007; Tang et al., 2000, 2002a, 2002b). Aplikasi teori tersebut dalam model kepuasan kerja menunjukan bahawa individu-individu yang mempunyai keinginan yang tinggi terhadap wang biasanya mempunyai kecenderungan yang tinggi untuk bertukar pekerjaaan bagi mencari kepuasan kerja di organisasi yang lain (Furham \& Argye, 1998; Ismail et al., 2008; Tang \& Kim, 1999).

Teori diskrepensi oleh Adams $(1963,1965)$ menerangkan bahawa persepsi seseorang individu terhadap pembahagian dan pertukaran sumber-sumber boleh mempengaruhi sikap dan tingkah laku mereka dalam organisasi. Sebagai contoh, apabila pekerja merasakan bahawa output berbentuk wang yang diterima adalah setimpal dengan input daripada usaha yang telah disumbangkannya, ini akan mendorong seseorang pekerja berfikir secara positif terhadap tugas dan tanggungjawab kerjanya. Akibat daripada keadaan ini, ia boleh menghalang pekerja tersebut untuk berhenti kerja secara sukarela. 
Seterusnya, dalam model diskrepensi oleh Lawler (1971) diterangkan bahawa kepuasan atau ketidakpuasan seseorang terhadap ganjaran adalah hasil daripada perbandingan di antara jumlah ganjaran yang diterima daripada majikan dengan jumlah ganjaran yang diinginkan oleh individu berkenaan. Apabila seseorang pekerja merasakan bahawa tugas dan tanggungjawab kerjanya adalah setimpal dengan pendapatan yang diterima, maka hal ini akan meningkatkan kepuasan beliau terhadap kerjanya. Apabila perasaan sedemikian wujud, ia boleh mendorong seseorang pekerja untuk membatalkan hasratnya daripada berhenti kerja secara sukarela.

Kajian literatur di atas telah dijadikan dasar bagi membentuk kerangka konseptual bagi kajian ini seperti yang ditunjukkan dalam Rajah 1.

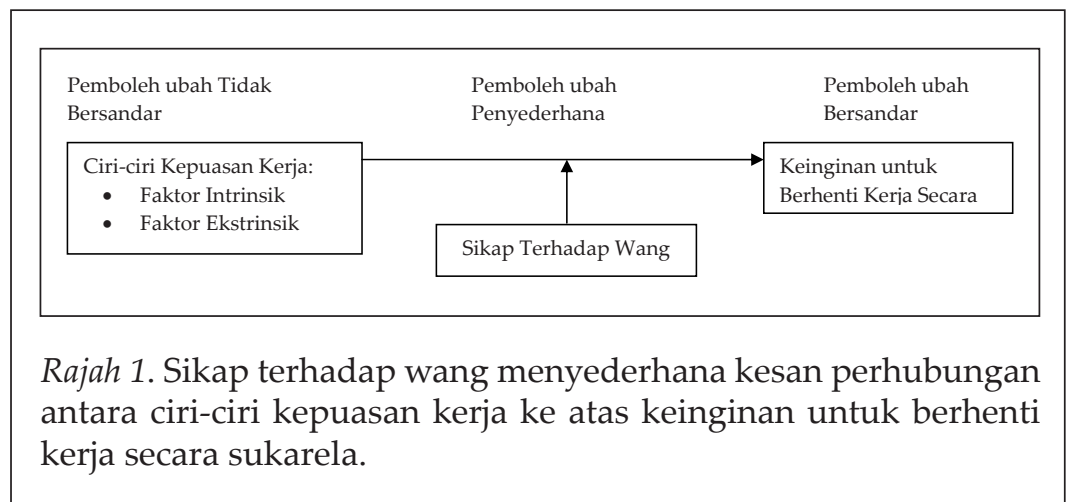

Berdasarkan kerangka konseptual kajian di atas, hipotesis-hipotesis yang akan diuji adalah:

H3: Sikap terhadap wang menyederhana kesan kepuasan kerja intrinsik ke atas keinginan untuk berhenti kerja secara sukarela.

H4: Sikap terhadap wang menyederhana kesan kepuasan kerja ekstrinsik ke atas keinginan untuk berhenti kerja secara sukarela.

\section{Metodologi}

\section{Reka Bentuk Kajian}

Reka bentuk kajian ini menggunakan kaedah keratan rentas yang membenarkan pengkaji menggunakan kajian literatur, temu duga 
terperinci, kajian rintis dan kajian soal selidik sebagai prosedur utama dalam pengumpulan data kajian. Kaedah ini berupaya membantu pengumpulan data secara tepat, mengelakkan pilih kasih, relevan dengan keperluan sesuatu kajian dan boleh dipercayai untuk mengukur persepsi responden terhadap pemboleh ubah kajian (Leedy \& Ormrod, 2005; Sekaran, 2003).

Temu duga terperinci dikendali mengikut garis panduan yang telah di sediakan oleh Easterby-Smith, Thorpe \& Lowe (1991), Wright (1996), dan Usunier (1998). Langkah pertama dalam prosedur temu duga ini, pengkaji telah menyediakan soalan-soalan temu duga fleksibel yang berkaitan dengan lima isu utama: ciri-ciri kepuasan kerja; ciri-ciri sikap terhadap wang; ciri-ciri keinginan untuk berhenti kerja secara sukarela, perkaitan di antara kepuasan kerja dan keinginan untuk berhenti kerja secara sukarela; dan perkaitan kaitan antara kepuasan kerja, sikap terhadap wang, dan keinginan untuk berhenti kerja secara sukarela.

Langkah kedua, teknik pensampelan purposif telah digunakan untuk mengadakan temu bual dengan seorang pegawai daripada bahagian pengurusan sumber manusia dan dua orang pekerja sokongan yang berkhidmat lebih 10 tahun di organisasi kajian. Pemilihan mereka berasaskan kepada pertimbangan pengkaji bahawa mereka yang terpilih adalah daripada kalangan individu yang memahami dan berpengalaman dalam program pembangunan dan pengurusan sumber manusia di organisasi tersebut. Maklumat temu duga secara terperinci menerangkan bahawa sistem perjawatan di organisasi kajian terbahagi kepada dua jenis iaitu bahagian pentadbiran dan bahagian teknikal. Pekerja pentadbiran terdiri daripada staf kumpulan pengurusan (seperti pengurus sumber manusia, pengurus kewangan dan pengurus korporat) dan staf kumpulan sokongan yang menjalankan tugas-tugas pentadbiran di pejabat dan menguatkuasa peraturan-peraturan penguasa tempatan. Pekerja teknikal pula terdiri daripada kumpulan pengurusan profesional (seperti jurutera, arkitek, juru ukur bahan dan perancang bandar) dan juruteknik-juruteknik yang terlibat dalam kerja-kerja pembinaan dan penyelenggaraan kerosakan dalam kawasan pentadbiran penguasa tempatan. Keseluruhan pekerja organisasi ini dibayar gaji dan menikmati kemudahan-kemudahan yang bersesuaian dengan kelayakan dan jawatan masing-masing. Mereka juga mendapat imbuhan asas dan tambahan (seperti elaun perkhidmatan, bonus dan insurans) sekiranya menjalankan tugas-tugas rasmi yang merbahaya dan bekerja di luar waktu kerja rasmi. 
Dari segi perancangan perjawatan dalam organisasi ini, ia perlu mendapatkelulusan dariKerajaanPersekutuan. Walaubagaimanapun, pembayaran ganjaran termasuk gaji dan bonus serta imbuhanimbuhan lain yang diperuntukkan kepada kakitangannya ditentukan oleh kemampuan kewangan organisasi ini sendiri. Hal ini bermakna peruntukan ganjaran yang diterima seseorang pekerja akan menjadi semakin baik apabila beliau telah berkhidmat lebih lama atau mencapai prestasi kerja yang tinggi. Kriteria ganjaran seumpama ini dianggap dapat meningkatkan tahap kepuasan pekerja terutama apabila jumlah wang yang mereka terima daripada majikan dipercayai dapat memenuhi keperluan masing-masing, lantas mendorong pekerja untuk tidak berhenti kerja secara sukarela. Sungguhpun perhubungan sebegini diyakini pihak pengurusan wujud, namun peranan sikap terhadap wang sebagai pemboleh ubah penyederhana masih belum jelas diketahui dalam organisasi kajian.

Langkah ketiga, maklumat temu duga tersebut telah dibandingkan dengan kajian literatur yang berkaitan bagi meletakan kajian ini dalam konteks yang betul. Hasil perbandingan ini telah digunakan untuk mengkelas dan menyusun maklumat mengikut setiap pemboleh ubah kajian dalam jadual analisa kandungan bagi memahami gejala-gejala yang dikaji. Langkah terakhir, maklumat yang telah dikategori dan disusun tersebut telah diguna pakai sebagai garis panduan untuk menyedia kandungan borang soal selidik bagi kajian rintis. Seterusnya, satu kajian rintis telah dilaksanakan dengan membincangkan borang soal selidik dengan peserta temu duga di atas. Maklum balas yang diterima daripada peserta tersebut telah diguna pakai untuk mengesahkan tahap kerelevan, kepentingan, kesesuaian dan kejelasan soalan-soalan, serta keseluruhan format borang soal selidik bagi kajian sebenar. Kaedah penterjemahan balik (back translation) seperti dianjurkan oleh Hulland (1999) dan Wright (1996) telah dilakukan pada borang soal selidik ke dalam bahasa Melayu dan bahasa Inggeris bagi menjamin dan mempertingkatkan kesahan serta kebolehpercayaan skala pengukuran kajian.

\section{Skala Pengukuran}

Jadual 1 menunjukan bahawa borang soal selidik kajian ini mengandungi empat bahagian utama: kepuasan kerja intrinsik, kepuasan kerja ekstrinsik, sikap terhadap wang, dan keinginan untuk berhenti kerja secara sukarela. Kesemua item diukur berdasarkan skala tujuh pilihan jawapan yang bermula dari "Sangat Tidak Setuju/ Tidak Puas Hati" (skor 1) hingga "Sangat Setuju/Puas Hati" (skor 7). Ciri-ciri responden kajian ini telah digunakan sebagai pemboleh ubah kawalan kerana kajian ini menfokuskan terhadap sikap pekerja. 


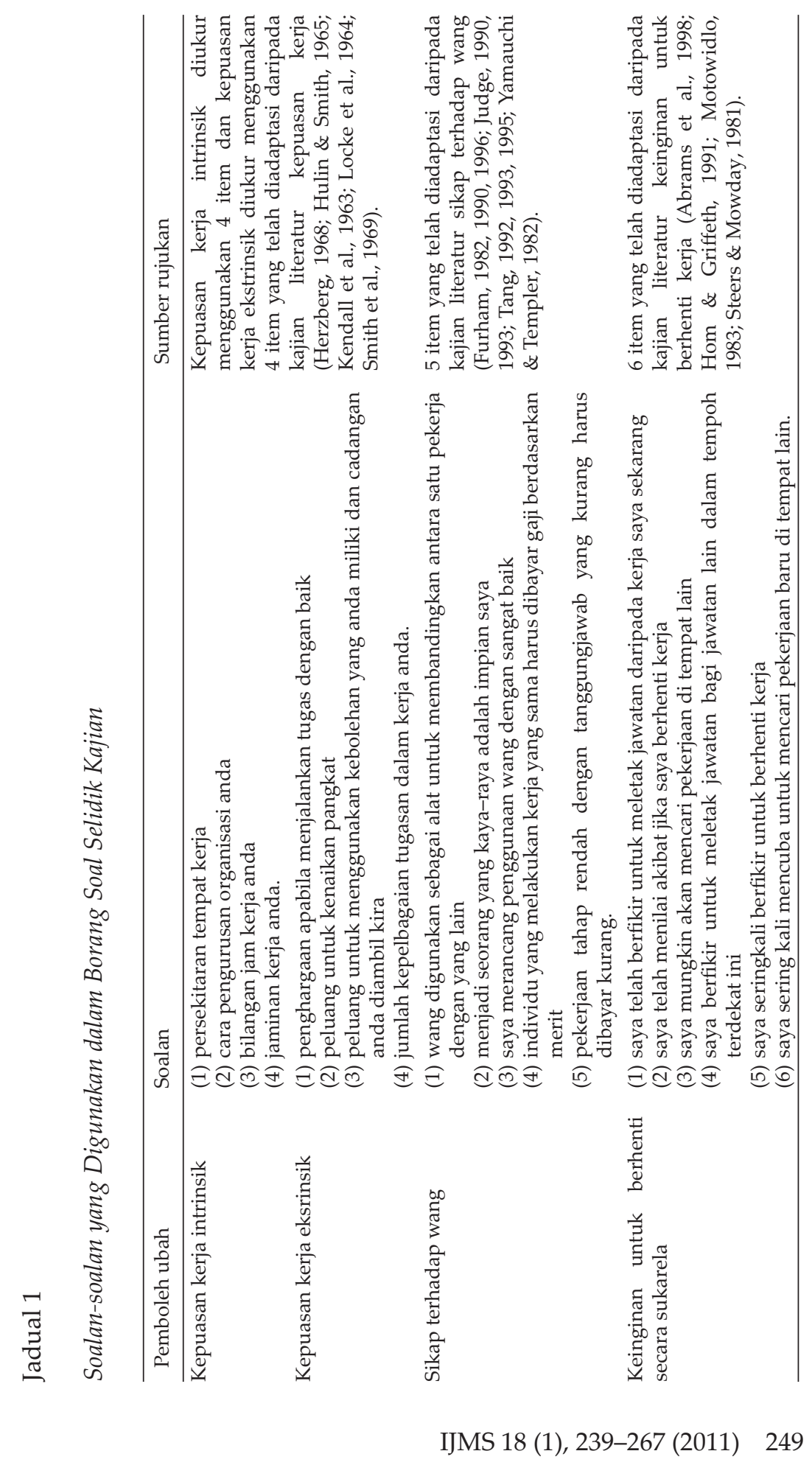




\section{Unit Analisis dan Persampelan}

Unit analisis kajian ini terdiri daripada pekerja yang telah berkhidmat di sebuah organisasi pihak penguasa tempatan di Malaysia Timur, Malaysia. Sebelum borang soal selidik kajian ini diedarkan, pengkaji telah mendapat persetujuan daripada ketua organisasi ini dan mendapat pandangan beliau tentang peraturan mengumpul data di organisasi beliau. Setelah mengambil kira keadaan peraturan organisasi ini, sampel kuota telah digunakan untuk menentukan saiz sampel berdasarkan kemampuan kewangan dan tempoh kajian yang pendek, iaitu 300 orang. Kemudian, teknik pensampelan mudah telah digunakan untuk mengedar sejumlah 300 borang soal selidik kepada pekerja di pelbagai jabatan melalui bantuan pihak pengurus dan penolong pengurus bahagian sumber manusia organisasi berkenaan. Teknik pensampelan mudah terpaksa digunakan dalam kajian ini kerana pengkaji tidak diberikan senarai pekerja yang berdaftar dan dikehendaki mengedarkan borang-borang soal selidik kepada pekerja melalui Pejabat Pengurus Sumber Manusia. Keadaan ini menghalang pengkaji untuk memilih sampel kajian melalui teknik pensampelan rawak. Daripada jumlah itu, 140 borang soal selidik yang lengkap diisi telah dikembalikan kepada penyelidik. Borang soal selidik kajian ini dijawab berdasarkan kerelaan dan persertujuan responden kajian. Jumlah sampel kajian ini dianggap mencukupi kerana telah melebehi jumlah sampel minimum iaitu 30 individu bagi membolehkan hipotesis-hipotesis kajian ini diuji menggunakan analisis statistik inferens (Cresswell, 1998; Sekaran, 2003).

\section{Analisa Data}

Pakej Statistik untuk Sains Sosial (SPSS) versi 16.0 telah digunakan untuk menganalisis tahap psikometrik dari data soal selidik berdasarkan garis panduan yang disyorkan oleh Hair, Anderson, Tatham \& Black (2006), dan Nunally dan Bernstein (1994). Walaubagaimanapun, sebelum analisis faktor dilakukan ke atas data tersebut, satu ujian bagi mengenal pasti kecukupan saiz sampel kajian perlu dilakukan (Hair et al., 2006; dan Nunally \& Bernstein, 1994). Di sini, ujian Kaiser-Meyer-Olkin (KMO) telah dilakukan bagi menunjukkan item-item dalam analisis mencapai nilai 0.6 dan lebih. Hal itu juga bagi memastikan ujian sferasiti Bartlett adalah signifikan, agar saiz sampel kajian diyakini mencukupi untuk dilakukan ujian kesahan dan kebolehpercayaan bagi skala pengukuran. Selain itu, usaha memeriksa kesahan data borang soal selidik melalui teknik direct oblimin juga telah dilakukan. Hal ini bertujuan untuk mengenal pasti item-item yang mewakili setiap pemboleh ubah kajian telah mencapai nilai 0.40 dan lebih. Seterusnya, dilakukan penilaian ke 
atas setiap pemboleh ubah kajian bagi menentukan sama ada setiap pemboleh ubah ujian telah mencapai nilai Eigen 1 dan lebih, serta nilai alpha Cronbach mencapai 0.70 dan lebih. Hal ini dilakukan dengan tujuan untuk memastikan sama ada pemboleh ubah kajian adalah sah dan boleh dipercayai. Lanjutan daripada ujian di atas, analisis korelasi Pearson juga telah digunakan untuk memeriksa masalah kolineariti dan menganggarkan tahap kebolehpercayaan di antara pemboleh ubah kajian.

Selain itu, prosedur pengujian kesan pemboleh ubah penyederhana ke atas darjah keteguhan perhubungan antara pemboleh ubah tidak bersandar dan pemboleh ubah bersandar telah dilakukan. Menurut Jaccard et al. (1990), hal ini perlu dilakukan bagi menentukan sama ada berlaku perubahan jika pemboleh ubah lain wujud dalam perhubungan tersebut. Akhir sekali, berikutan kekurangan yang terdapat pada analisis kolerasi Pearson yang tidak berkeupayaan untuk menentukan kesan pemboleh ubah penyederhana dalam model konseptual kajian, maka analisis regresi berganda hierarki yang disyorkan oleh Cohen dan Cohen (1983) telah digunakan. Analisis regresi ini mampu menunjukan kehadiran kesan pemboleh ubah penyederhana dalam kerangka konseptual apabila interaksi antara pemboleh ubah tidak bersandar dan pemboleh ubah penyederhana mempunyai hubungan yang signifikan dengan pemboleh ubah bersandar (contohnya, pada tahap siginifikan $\mathrm{p}=<0.05$; $\mathrm{p}=<0.01$; $\mathrm{p}=<0.001$ ). Sekiranya analisis regresi hierarki menunjukan bahawa perhubungan langsung antara pemboleh ubah tidak bersandar dan pemboleh ubah bersandar adalah signifikan, ia tidak akan menganggu tahap signifikan yang terdapat pada pemboleh ubah penyederhana itu (Baron \& Kenny, 1986). Sebaliknya, jika nilai korelasi berganda kuasa dua bagi pemboleh ubah penyederhana lebih tinggi daripada pemboleh ubah tidak bersandar, ini bererti pemboleh ubah penyederhana mempunyai kesan ke atas darjah kekuatan dalam sampel data (Cohen \& Cohen, 1983; Jaccard, Turrisi \& Wan 1990).

\section{Dapatan Kajian}

\section{Latar Belakang Responden}

Jadual 1 memaparkan profil responden untuk kajian ini mengikut latar belakang demografi, sosial dan ekonomi. Kebanyakan responden kajian ini adalah perempuan (56.4\%), berumur antara 26-35 tahun (45.0\%), berpendidikan SPM (42.1\%), berkhidmat 1-5 tahun (25.7\%), staf teknikal (82.9\%), dan berpendapatan bulanan di antara RM1000 - RM1999 (53.6\%). 
Jadual 1

Ciri-ciri Responden Kajian ( $N=140)$

\begin{tabular}{|c|c|c|}
\hline Ciri-ciri umum responden & Ciri khusus & Peratusan \\
\hline \multirow[t]{2}{*}{ Jantina } & Lelaki & 43.6 \\
\hline & Perempuan & 56.4 \\
\hline \multirow[t]{4}{*}{ Umur } & 18-25 tahun & 13.6 \\
\hline & 26-35 tahun & 45.0 \\
\hline & $36-45$ tahun & 26.4 \\
\hline & $>46$ tahun & 15.0 \\
\hline \multirow[t]{6}{*}{ Pendidikan } & Sarjana & 1.4 \\
\hline & Sarjana muda & 10.7 \\
\hline & Diploma & 22.9 \\
\hline & STPM & 6.4 \\
\hline & SPM/MCE & 42.1 \\
\hline & SRP/LCE/PMR & 16.4 \\
\hline \multirow[t]{6}{*}{ Lama berkhidmat } & $<1$ tahun & 7.9 \\
\hline & 1-5 tahun & 25.7 \\
\hline & 6-10 tahun & 20.7 \\
\hline & 11-15 tahun & 15.7 \\
\hline & 16-20 tahun & 5.7 \\
\hline & $>21$ tahun & 24.3 \\
\hline \multirow[t]{2}{*}{ Jawatan } & Staf pentadbiran & 17.1 \\
\hline & Staf teknikal & 82.9 \\
\hline \multirow[t]{6}{*}{ Gaji bulanan } & $<$ RM 800 & 2.9 \\
\hline & RM 800 - RM 999 & 17.9 \\
\hline & RM 1000 - RM 1999 & 53.6 \\
\hline & RM 2000 - RM 2999 & 21.4 \\
\hline & RM 3000 - RM 3999 & 3.6 \\
\hline & $>$ RM 4000 & 0.7 \\
\hline
\end{tabular}

Nota. SRP/LCE/PMR: Sijil Rendah Pelajaran Malaysia/Lower Certificate of Education /Penilaian Menengah Rendah SPM/MCE: Sijil Pelajaran Malaysia/Malaysia Certificate of Education STPM: Sijil Tinggi Pelajaran Malaysia

\section{Kesahan dan Kebolehpercayaan Skala Pengukuran}

Jadual 2 menunjukkan bahawa skala pengukuran yang digunakan telah mencapai tahap kesahan dan kebolehpercayaan yang memuaskan dan seterusnya digunakan dalam pengujian hipotesishipotesis kajian.

252 IJMS 18 (1), 239-267 (2011) 

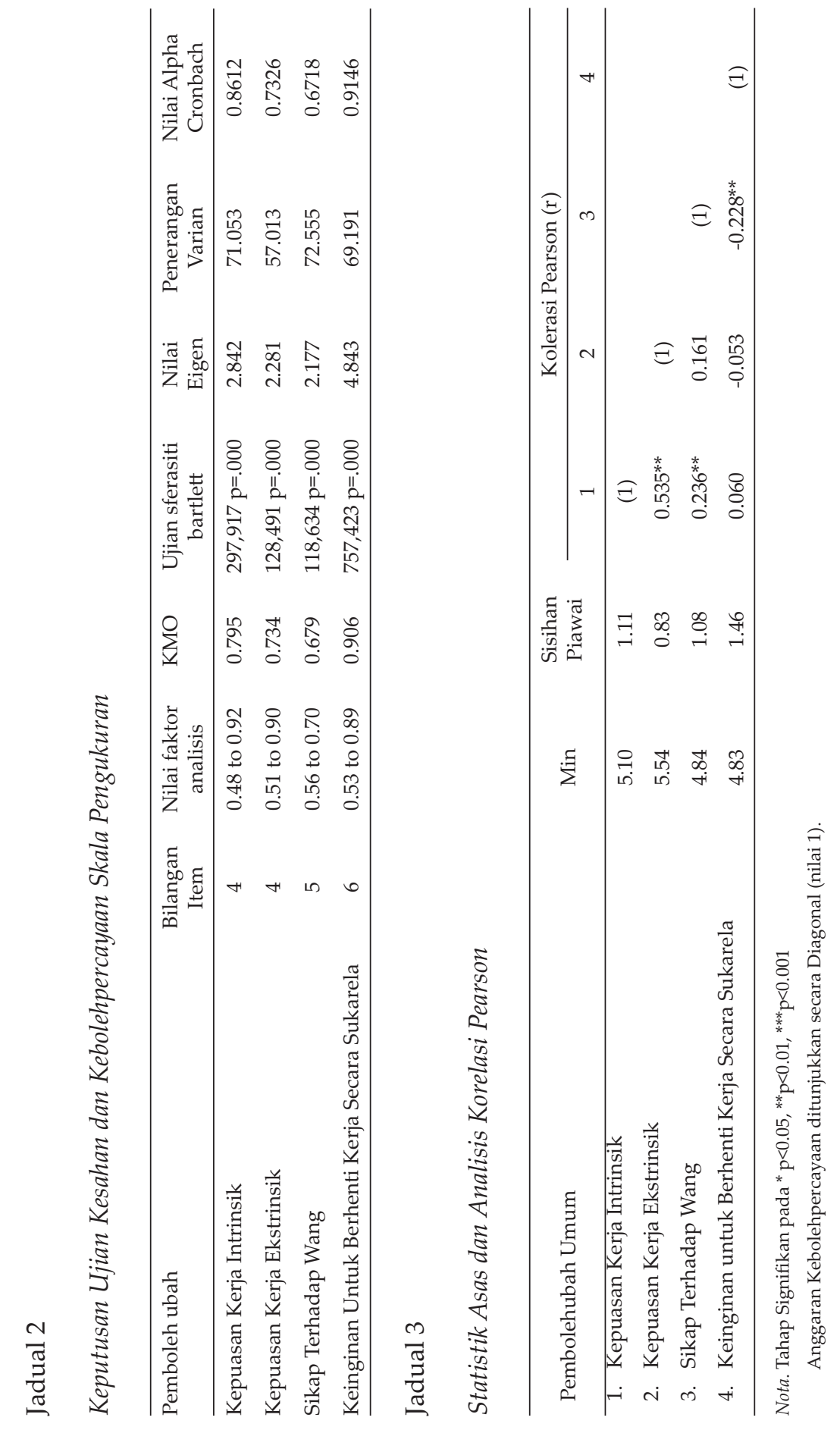

IJMS 18 (1), 239-267 (2011) 253 
Jadual 3 pula memaparkan hasil analisis statistik deskriptif dan korelasi Pearson. Nilai min untuk pembolehubah kajian ini berada di antara 4.83 dan 5.54. Hal ini bererti bahawa tahap kepuasan kerja intrinsik dan kepuasan kerja ekstrinsik, sikap terhadap wang, dan keinginan untuk berhenti kerja secara sukarela berada di antara tahap sederhana (4) dan sangat tinggi (7). Pekali kolerasi bagi perhubungan antara pemboleh ubah tidak bersandar (kepuasan kerja intrinsik dan kepuasan kerja ekstrinsik), pemboleh ubah penyederhana (sikap terhadap wang), dan pemboleh ubah bersandar (keinginan untuk berhenti kerja secara sukarela) pula mempunyai nilai yang rendah daripada 0.90. Hal ini membuktikan bahawa pemboleh ubah kajian ini adalah bebas daripada masalah kolineariti dan skala pengukuran kajian ini telah mencapai tahap kesahan dan kebolehpercayaan yang tinggi (Hair et al., 2006).

Keputusan pengujian model kesan langsung menunjukan bahawa kepuasan kerja intrinsik mempunyai hubungan yang tidak signifikan dengan keinginan untuk berhenti kerja secara sukarela $(\mathrm{r}=0.060$, $\mathrm{p}>0.05$ ), oleh itu H1 tidak disokong. Manakala, kepuasan kerja ekstrinsik mempunyai hubungan yang tidak signifikan dengan keinginan untuk berhenti kerja ( $\mathrm{r}=-0.053$, $\mathrm{p}>0.05)$, oleh itu $\mathrm{H} 2$ tidak disokong. Dapatan ini mengesahkan bahawa kepuasan kerja intrinsik dan kepuasan kerja ekstrinsik tidak bertindak sebagai faktor yang mempengaruhi keinginan untuk berhenti kerja di organisasi kajian.

\section{Keputusan Pengujian Model Pembolehubah Penyederhana}

Jadual 4 menunjukan keputusan analisa regresi hierarki dalam tiga model. Model 1 menunjukkan bahawa faktor demografi responden didapati tidak mempengaruhi secara signifikan keinginan untuk berhenti kerja secara sukarela. Kemasukan faktor demografi responden ke dalam model ini telah menyumbang sebanyak 4 peratus kepada perubahan dalam pemboleh ubah bersandar. Model 2 memaparkan bahawa kepuasan kerja intrinsik didapati tidak berupaya mempengaruhi secara signifikan keinginan untuk berhenti kerja secara sukarela (Model 2: $\beta=-0.15, p>0.05$ ), dan kepuasan kerja ekstrinsik didapati berupaya mempengaruhi secara signifikan keinginan untuk berhenti kerja secara sukarela (Model 2: $\beta=0.21$, $\mathrm{p}<0.05)$. Kemasukan pemboleh ubah tidak bersandar ke dalam model ini telah menyumbang sebanyak 14 peratus kepada perubahan dalam pemboleh ubah bersandar.

Model 3 menerangkan bahawa interaksi antara kepuasan kerja intrinsik dan sikap terhadap wang mempunyai hubungan yang 
signifikan dengan keinginan untuk berhenti kerja secara sukarela (Model 3: $\beta=-1.44, \mathrm{p}<0.01$ ), dan hal ini bererti H3 adalah disokong. Manakala, interaksi antara kepuasan kerja ekstrinsik dan sikap terhadap wang mempunyai hubungan yang tidak signifikan dengan keinginan untuk berhenti kerja secara sukarela (Model 3: $\beta=0.53$, $\mathrm{p}>0.05)$, dan hal ini bererti H4 tidak disokong. Sebelum kemasukan pemboleh ubah penyederhana dalam Model 3, kepuasan kerja intrinsik mempunyai hubungan yang tidak signifikan dengan keinginan untuk berhenti kerja secara sukarela (Model 2: $\beta=-0.15$, $\mathrm{p}>0.05)$, tetapi kepuasan kerja ekstrinsik didapati mempunyai hubungan yang signifikan dengan keinginan untuk berhenti kerja secara sukarela (Model 2: $\beta=0.21, p<0.05$ ). Setelah kemasukan pemboleh ubah penyederhana ke dalam Model 3, hubungan yang tidak signifikan di antara kepuasan kerja intrinsik dan keinginan untuk berhenti kerja secara sukarela tidak berubah kepada signifikan (Model 3: $\beta=0.84, p>0.05$ ), dan hubungan yang signifikan di antara kepuasan kerja ekstrinsik dan keinginan untuk berhenti kerja secara sukarela tidak berubah kepada signifikan (Model 3: $\beta=-0.10, p>0.05$ ). Dari segi saiz kesan, kemasukan pemboleh ubah penyederhana dalam Model 3 ini telah menyumbang sebanyak 18 peratus kepada perubahan dalam pemboleh ubah bersandar.

Keputusan statistik ini menerangkan bahawa sikap positif terhadap wang di kalangan pekerja yang mempunyai kepuasan kerja intrinsik berupaya mengurangkan keinginan pekerja untuk berhenti kerja secara sukarela. Sebaliknya, sikap positif terhadap wang di kalangan pekerja yang mempunyai kepuasan kerja ekstrinsik tidak berupaya mengurangkan keinginan pekerja untuk berhenti kerja secara sukarela. Secara keseluruhan, dapatan kajian ini memberi isyarat yang jelas bahawa sikap terhadap wang hanya berkuasa sebagai pemboleh ubah penyederhana separa dalam model kepuasan kerja di organisasi kajian.

\section{Perbincangan dan Implikasi}

Keputusan kajian ini menunjukkan bahawa sikap terhadap wang hanya bertindak sebagai pemboleh ubah penyederhana separa di antara kepuasan kerja dan keinginan untuk berhenti secara sukarela. Dalam organisasi kajian, pekerja melaksanakan tugas dan tanggungjawab mengikut fail meja jawatan masing-masing. Pekerja yang ditemuduga melahirkan perasaan puas hati yang tinggi terhadap pekerjaan. Pekerja juga menunjukan reaksi positif terhadap wang yang diterima daripada majikan. Dari segi korelasi, pekerja yang mempunyai tahap kepuasan kerja intrinsik yang tinggi merasa 
tidak ingin untuk berhenti kerja secara sukarela kerana mereka percaya bahawa ganjaran wang yang diterima daripada pekerjaan dapat memenuhi kehendak dan pengharapan mereka.

Jadual 4

Keputusan Ujian Analisis Regresi Hierarki

\begin{tabular}{|c|c|c|c|}
\hline \multirow[t]{2}{*}{ Pemboleh ubah } & \multicolumn{3}{|c|}{$\begin{array}{l}\text { Pemboleh ubah Bersandar } \\
\text { (Keinginan untuk Berhenti } \\
\text { Kerja Secara Sukarela) }\end{array}$} \\
\hline & Model 1 & Model 2 & Model 3 \\
\hline \multicolumn{4}{|l|}{ Pemboleh Ubah Kawalan } \\
\hline Jantina & -0.16 & -0.16 & $-0.17^{*}$ \\
\hline Jawatan & 0.17 & 0.21 & $0.22^{*}$ \\
\hline Umur & 0.03 & 0.17 & 0.12 \\
\hline Pendidikan & -0.04 & -0.10 & -0.11 \\
\hline Lama berkhidmat & 0.01 & -0.00 & 0.02 \\
\hline Gaji Bulanan & 0.06 & 0.04 & 0.08 \\
\hline \multicolumn{4}{|l|}{$\underline{\text { Pemboleh Ubah Tidak Bersandar }}$} \\
\hline Kepuasan Kerja Intrinsik & & -0.15 & 0.84 \\
\hline Kepuasan Kerja Ekstrinsik & & $0.21^{*}$ & -0.10 \\
\hline Sikap Terhadap Wang & & $-0.30^{* *}$ & 0.22 \\
\hline Pemboleh Ubah Penyederhana & & & \multirow{3}{*}{$\begin{array}{c}-1.44^{* *} \\
0.53\end{array}$} \\
\hline Kepuasan Kerja Intrinsik X Sikap Terhadap Wang & & & \\
\hline Kepuasan Kerja Ekstrinsik X Sikap Terhadap Wang & & & \\
\hline $\mathrm{R}^{2}$ & 0.04 & 0.14 & 0.18 \\
\hline Adjusted R Square & 0.00 & 0.08 & 0.11 \\
\hline $\mathrm{F}$ & 0.10 & $2.34^{* *}$ & $2.54^{* *}$ \\
\hline R Square Change & 0.04 & 0.10 & 0.04 \\
\hline $\mathrm{F} \Delta \mathrm{R}$ Square & 0.10 & $4.85^{* *}$ & $3.09^{*}$ \\
\hline
\end{tabular}

Nota. Signifikan pada ${ }^{*} \mathrm{p}<0.05 ;{ }^{* *} \mathrm{p}<0.01 ;{ }^{* * *} \mathrm{p}<0.001$

Implikasi kajian ini dibahagikan kepada tiga aspek: teori, kaedah penyelidikan dan pengamal sumber manusia. Dari perspektif teori, dapatan kajian ini menunjukan dua penemuan penting. Pertama, interaksi di antara kepuasan kerja intrinsik dan sikap positif terhadap wang berjaya mengurangkan keinginan untuk berhenti kerja secara sukarela. Dapatan ini menyokong kajian-kajian lepas seperti yang dilaksanakan oleh Tang et al. (1995, 2000, 2004a, 2004b). Kedua, interaksi di antara kepuasan kerja ekstrinsik dan sikap positif terhadap wang didapati tidak berjaya mengurangkan keinginan untuk berhenti

256 IJMS 18 (1), 239-267 (2011) 
kerja secara sukarela. Dapatan ini pula tidak menyokong kajian lepas seperti yang dikendalikan oleh Tang et al. (2000), dan Ismail et al. (2008).

Berdasarkan pengamatan yang mendalam terhadap dapatan temuduga terperinci, sikap positif terhadap wang tidak berupaya menyederhanakan kesan kepuasan kerja ekstrinsik ke atas keinginan untuk berhenti secara sukarela mungkin disebabkan oleh beberapa faktor luaran. Pertama, kebanyakan pekerja yang mempunyai kepuasan kerja ekstrinsik meletakkan keutamaan terhadap faktor fizikal kerja, seperti deskripsi tugas, peraturan kerja, protokol kerja dan kemudahan fizikal. Sekiranya seseorang pekerja merasa sukar untuk menyesuaikan diri dengan keadaan persekitaran luaran kerja, hal ini boleh mendorongnya untuk berhenti kerja secara sukarela bagi mencari kepuasan melaksanakan tugas di organisasi lain. Kedua, polisi dan prosedur yang perlu diikuti pihak pengurusan sumber manusia adalah seragam, formal dan rigid. Pengurus dan pekerja tidak diberi kuasa yang mencukupi untuk merancang sesuatu tugas yang sesuai dengan keadaan kognitif, emosi dan nilai-nilai pekerja. Bagi pekerja yang mementingkan ciri-ciri kerja ekstrinsik, keadaan ini boleh mendorong mereka untuk berhenti kerja bagi mencari kepuasan di organisasi yang lain.

Ketiga, kriteria pembahagian ganjaran kewangan lebih tertumpu kepada ciri-ciri kerja ekstrinsik seperti menjalin persahabatan dengan ketua atau penyelia berbanding menekankan kepada ciri-ciri kerja intrinsik seperti rasa kebertanggungjawaban terhadap tugas. Dalam situasi ini, kebolehan keterampilan diri semasa berhubung dengan ketua terdekat dan pegawai atasan adalah satu keistimewaan untuk memperoleh jawatan yang lebih tinggi dan menikmati ganjaran kerja yang lebih baik. Bagi seseorang pekerja yang mementingkan tugas akan merasa tidak puas hati dengan keadaan yang wujud, hal ini boleh membangkitkan keinginan dalam diri pekerja itu untuk mencari kepuasan di organisasi yang lain. Keempat, amalan komunikasi terbuka di antara pengurus dan pekerja kurang dilaksanakan. Para pengurus lebih gemar mematuhi peraturan dan protokol kerja bagi menjaga imej dan status quo daripada mengamalkan perbincangan, pertukaran maklumat dan perkongsian pengalaman secara terbuka, jujur dan akauntabiliti dengan pekerja. Keadaan ini boleh membangkitkan salah faham, prasangka buruk dan pandangan serong dalam kalangan pekerja yang mempunyai kepuasan ekstrinsik yang tinggi terhadap polisi dan prosedur penilaian prestasi kerja. Akibatnya, mereka lebih cenderung untuk berhenti kerja secara sukarela bagi mencari kepuasan di organisasi lain. 
Dari segi kaedah penyelidikan, borang soal selidik kajian ini direka berdasarkan data yang dikumpulkan melalui kajian literatur, temuduga terperinci, dan kajian rintis telah berjaya mencapai tahap kesahan dan kebolehpercayaan yang tinggi. Keadaan ini dapat membantu menghasilkan dapatan kajian yang tepat dan boleh dipercayai.

Dari sudut pengamal, dapatan kajian ini boleh digunakan sebagai panduan oleh pengurus sumber manusia untuk menambah baik program pembangunan dan pengurusan sumber manusia. Antara langkah yang perlu diambil kira bagi mencapai matlamat ini ialah: pertama, senarai tugas perlu direka bentuk dengan penglibatan bersama para pekerja. Cara ini dapat meningkatkan kefahaman, mengurangkan buruk sangka, membangkitkan perasaan kepunyaan dan rasa bertanggungjawab dalam diri pekerja terhadap tugas. Kedua, latihan bersesuaian dengan keperluan kerja perlu disediakan oleh pihak pengurusan. Kandungan latihan ini akan meningkatkan pengetahuan, kemahiran, kebolehan dan nilai-nilai moral yang baik dalam diri pekerja, lantas mendorong pekerja meningkatkan prestasi, kepuasan, komitmen dan etika dalam organisasi. Ketiga, perancangan merekrut pekerja perlu diubah daripada mengambil berdasarkan kelayakan akademik semata-mata kepada pemilihan mengikut berkelulusan akademik yang bersesuaian, dan mempunyai pengetahuan, pengalaman dan sahsiah yang baik bagi mengisi kekosongan jawatan-jawatan penting. Pekerja seumpama ini mempunyai kebolehan untuk membentuk ciri-ciri dalaman dan luaran kerja yang sesuai dengan pelbagai jenis jawatan, menyediakan proses kerja yang teratur bagi setiap jenis kerja, dan berupaya menggunakan kaedah melayan yang berhikmah, penuh kasih sayang dan tegas bagi mengendalikan pelbagai aduan dan tuntutan yang dibuat oleh pekerja.

Akhir sekali, kaedah penetapan ganjaran perlu mempertimbangkan keperluan individu pekerja. Sebagai contoh, pekerja yang berkeluarga, lama berkhidmat dan berprestasi tinggi perlu diberikan ganjaran yang lebih (seperti rawatan kesihatan, pakej pelancongan sebagai insentif untuk diri staf dan keluarga dan imbuhan-imbuhan tambahan selain dari gaji pokok) bagi menghargai jasa, pengorbanan dan kesetiaan mereka kepada organisasi. Sekiranya cadangan-cadangan di atas diberi perhatian yang sewajarnya, hal ini akan meningkatkan sikap dan gelagat pekerja yang positif termasuk meningkatkan kepuasan, komitmen, prestasi dan amalan beretika yang baik di tempat kerja. Hal ini seterusnya boleh membantu menjayakan matlamat dan strategi organisasi ke arah lebih cemerlang. 


\section{Kesimpulan}

Kajian ini mencadangkan kerangka konseptual berdasarkan kajian literatur yang berkaitan dengan kepuasan kerja. Pemboleh ubah yang digunakan dalam kajian ini mempunyai tahap kesahan dan kebolehpercayaan yang tinggi. Keputusan analisis regresi hierarki mengesahkan bahawa sikap positif terhadap wang berupaya menyederhanakan kesan kepuasan kerja instrinsik ke atas keinginan pekerja untuk berhenti kerja. Dapatan ini menerangkan bahawa sikap terhadap wang di kalangan pekerja yang mempunyai kepuasan kerja intrinsik (contohnya, tidak mementingkan ganjaran kebendaan) mampu menghalang hasrat mereka untuk berhenti kerja secara pilihan. Manakala, sikap positif terhadap wang tidak berupaya menyederhanakan kesan kepuasan kerja ekstrinsik ke atas keinginan pekerja untuk berhenti kerja secara pilihan. Dapatan ini menghuraikan bahawa sikap positif terhadap wang di kalangan pekerja yang mempunyai kepuasan kerja ekstrinsik (contohnya, mementingkan ganjaran kebendaan) tidak pula mampu menghalang hasrat mereka untuk berhenti kerja secara pilihan. Oleh itu, dapatan kajian ini mengesahkan bahawa sikap terhadap wang hanya bertindak sebagai pemboleh ubah penyederhana separa dalam model kepuasan kerja di organisasi kajian. Seterusnya, kajian akan datang perlu mengiktiraf sikap terhadap wang sebagai elemen penting dalam model kepuasan kerja. Cadangan ini menjangkakan bahawa kewujudan sikap yang positif terhadap wang boleh menghalang pekerja untuk berhenti kerja secara sukarela dan sebaliknya meningkatkan sikap serta tingkah laku yang positif terutama dari segi komitmen, prestasi dan etika kerja. Seterusnya, keadaan ini boleh mendorong pekerja untuk meningkatkan tahap daya saing organisasi di pasaran ekonomi global.

Kesimpulan kajian ini mengambil kira batasan kerangka konseptual danmetodologikajian. Pertama, kaedahkeratan rentasyang digunakan dalam kajian ini tidak dapat mengesan isu-isu pembangunan atau/ dan sebab-sebab berlakunya perhubungan di antara pembolehubahpembolehubah yang lebih khusus. Kedua, kajian ini tidak mengenengahkan perhubungan di antara indikator-indikator khusus bagi pemboleh ubah tidak bersandar, pemboleh ubah penyederhana dan pemboleh ubah bersandar. Ketiga, keputusan analisis regresi berganda hanya memfokuskan kepada penerangan tentang varian tahap prestasi berdasarkan persamaan regresi (Tabachnick, Barbara \& Fidell 2001), tetapi masih banyak lagi faktor lain yang penting tidak dihuraikan. Sebagai contoh, kandungan tugas, sifat tugas, ganjaran, persekitaran fizikal dan kaedah mengurus kerja perlu diperincikan 
dalam kepuasan kerja. Manakala gaji, bonus dan elaun perlu dikelasifikasikan dalam sikap terhadap wang. Seterusnya, keinginan untuk berhenti kerana persaraan awal, keinginan untuk berhenti kerana mendapat tawaran yang lebih baik, dan keinginan untuk berhenti kerana tujuan peribadi perlu diasingkan dalam keinginan untuk berhenti kerja secara sukarela. Sekiranya faktor ini diambil kira dalam analisis regresi ia dapat menentukan secara jelas tentang sifat perhubungan di antara pemboleh ubah tidak bersandar dan pemboleh ubah bersandar, serta menganggarkan darjah kekuatan perhubungan di antara pemboleh ubah tersebut.

Keempat, kebanyakan responden kajian ini berketurunan bumiputera dan persepsi kumpulan ini mungkin lebih banyak mempengaruhi dapatan kajian ini. Kelima, kajian ini menggunakan teknik pensampelan mudah bagi mengumpul data daripada pekerja tempatan yang berkhidmat di sebuah organisasi. Kelima, akhir sekali, dapatan kajian ini hanya mencerminkan sifat interaksi yang wujud di antara pembolehubah-pembolehubah kajian umum dalam sebuah penguasa tempatan. Keenam, bias secara sistematik atau varian metod umum yang mempengaruhi tahap korelasi yang tinggi di antara pemboleh ubah kajian sukar untuk dielakkan kerana borang soal selidik ini dijawab oleh responden yang bersifat homogenous. Batasan-batasan di atas boleh mengurangkan keupayaan dapatan kajian ini untuk digeneralisasikan kepada pelbagai latar organisasi yang berlainan.

Kekurangan kajian ini perlu dijadikan sebagai panduan bagi memperkukuhkan kaedah penyelidikan dan kerangka teori kepuasan kerja dalam kajian akan datang. Pertama, elemen-elemen yang berkaitan dengan kepuasan kerja, sikap dan tingkah laku individu perlu ditambah supaya ia mampu menerangkan dengan lebih jelas sejauh mana berkesannya peranan sikap terhadap wang sebagai pemboleh ubah penyederhana dalam kerangka konseptual kajian. Kedua, faktor-faktor demografi (seperti jantina, umur, pendidikan, lama berkhidmat, jawatan dan gaji) dan organisasi (seperti bahagian, jabatan dan jenis) telah diabaikan dalam kerangka konseptual yang sedia ada. Sekiranya faktor-faktor demografi dan organisasi tersebut diambil kira ia boleh mengesan sejauh mana darjah kekuatan peranan sikap terhadap wang sebagai pemboleh ubah penyederhana dalam kerangka konseptual kajian. Ketiga, kekurangan yang terdapat dalam kaedah merentas seksyen boleh diatasi melalui penggabungan kaedah kajian berturutan (longitudinal study) bagi menghasilkan kesimpulan kajian yang mampu mengambil kira perkara-perkara yang lebih dinamik dalam sampel data. 
Keempat, kajian akan datang dapat menghasilkan kesimpulan yang lebih mantap apabila saiz sampel yang lebih besar diambil daripada beberapa organisasi melalui teknik persampelan rawak. Kelima, mengambil kira saranan literatur kepuasan kerja yang mengesyorkan bahawa kecintaan terhadap wang, nilai etika wang, dan kepuasan terhadap wang perlu dimasukkan sebagai pemboleh ubah penyederhana dalam analisis supaya kesan kepuasan kerja ke atas keinginan untuk berhenti secara sukarela dapat diukur dari perspektif yang lebih lengkap dan menghasilkan kesimpulan kajian yang lebih meyakinkan (Currall et al., 2005; Ismail et al., 2008; Tang, 2007; Tang et al., 2002a, 2002a, 2004a, 2004b). Akhir sekali, literatur kepuasan kerja menerangkan bahawa sikap dan tingkah laku individu boleh diterjemahkan dalam beberapa aspek, seperti komitmen, prestasi, setia dan etika (Charles \& Schwepker, 2001; Ismail et al., 2008; Judge, Thoresen, Bono \& Patten 2001; Mrayyan, 2007; Wu \& Norman, 2006). Sekiranya aspek-aspek sikap dan tingkah laku tersebut dihubungkan dengan kepuasan kerja, ia akan dapat menunjukkan dengan jelas aspek-aspek sikap dan tingkah laku yang mana lebih kuat disederhanakan oleh sikap terhadap wang. Cadangan-cadangan yang dibincangkan di atas perlu diberi perhatian yang sewajarnya bagi memantapkan lagi kajian akan datang.

\section{Rujukan}

Adams, J. S. (1963). Toward an understanding of inequity. Journal of Abnormal and Social Psychology, 67, 422-436.

Adams, J. S. (1965). Inequity in social exchange: Advances in experimental social psychology. New York: Academic Press.

Abrams, D., Ando, K., \& Hinkle, S. (1998). Psychological attachment to the group: Cross-cultural differences in organizational identification and subjective norms as predictors of workers' turnover intentions. Personality and Social Psychology Bulletin, 24(10), 1027-1039.

Ajzen, I., \& Fishbein, M. (1977). Attitude-behavior relations: A theoretical analyses and review of empirical research. Pychological Bulletin, 84(5), 888-917.

Applebaum, D. H. (2008). The relationship between physical work environmental factors, perceived stress, job satisfaction and turnover intention among inpatient acute care nurses (Doctor of public health dissertation). US: Rutgers the State University of New JerseyNew Brunswick and University of Medicine and Dentistry of New Jersey.

IJMS 18 (1), 239-267 (2011) 261 
Baron, R. M., \& Kenny, D. A. (1986). The moderator-mediator variable distinction in social psychological research: Conceptual, strategic, and statistical considerations. Journal of Personality and Social Psychology, 51(6), 1173-1182.

Campion, M. A. (1991). Meaning and measurement of turnover: Comparison of alternative measures and recommendations for research. Journal of Applied Psychology, 76(2), 199-212.

Charles, H., \& Schwepker, Jr. (2001). Ethical climate's relationship to job satisfaction, organizational commitment, and turnover intention in the salesforce. Journal of Business Research, 54(1), $39-52$.

Cohen, J., \& Cohen, P. (1983). Applied multiple regression/correlation analysis for the behavioral sciences. Hillsdale, N. J.: Erlbaum.

Cresswell, J. W. (1998). Qualitative inquiry and research design: Choosing among five traditions. London: Sage Publications.

Currall, S. C., Towler, A. J., Judge, T. A., \& Kohn, L. (2005). Pay satisfaction and organizational outcomes. Personnel Psychology, 58(3), 613-640.

DeConinck, J., \& Bachmann, D. (2005). An analysis of turnoer among retail buyers. Journal of Business Research, 58(97), 874-882.

Durvasula, S., \& Lysonski, S. (2007). Money attitudes, materialism, and achievement vanity: An investigation of young Chinese consumers' perceptions. International Marketing Conference on Marketing and Society.

Dougherty, T. W., Bluedorn, A. C., \& Keon, T. L. (1985). Precursors of employee turnover: A multiple sample casual analyses. Journal of Occupational Behavior, 6, 259-271.

Easterby-smith, M., Thorpe, R., \& Lowe, A. (1991). Management research: An introduction. London: Sage Publications.

Fisher, C., \& Locke, E. A. (1992). The new look in job satisfaction theory and research. New York: Lexington Books.

Furham, A. (1982). The protestant work ethic and attitudes towards unemployment. Journal of Occupational Psychology, 55, 277-285.

Furham, A. (1990). A content, correlational, and factor analytic study of seven questionnaire mesaures of the Protestant work ethic. Human Relations, 43(4), 383-399.

Furham, A. (1996). Attitudinal correlates and demographic predictors of money beliefs and behaviors. Journal of Organizational Behavior, 17, 373-388.

Furham, A., \& Argye, M. (1998). The psychology of money. London: Routledge.

Furham, A., \& Okamura, R. (1999). Your money or your life: Behavioral and emotional predictors of money pathology. Human Relations, $52,1157-1177$.

262 IJMS 18 (1), 239-267 (2011) 
Golembiewski, R. T. (1993). Handbook of organizations behavior. New York: Marcel Dekker.

Ghiselli, R. F., La Lopa, J. M., \& Bai, J. M. (2001). Job satisfaction, life satisfaction, and turnover intent food service managers. Cornell Hotel $\mathcal{E}$ Restaurant Administration Quarterly, 42 (2), 28-38.

Hair, J. F., Anderson, R. E., Tatham, R. L., \& Black, W. C. (2006). Multivariate data analysis. New Jersey: Prentice Hall.

Herzberg, F. (1968). One more time: How do you motivate employees? In S. J. Ott (Ed.). Classical reading in organizational behavior. Florida: Harcourt Brace \& Company.

Hoon, L. S., \& Lim, V. K. (2001). Attitudes towards money and work: Implications for Asian management style following the economic crisis. Journal of Managerial Psychology, 16(2), 159-172.

Hom, P. W., \& Griffeth, R. W. (1991). Structural equations modeling test of a turnover theory: Cross-sectional and longitudinal analyses. Journal of Applied Psychology, 76(3), 350-366.

Hulland, J. (1999). Use of partial least square (PLS) in strategic management research: A review of four recent studies. Strategic Management Journal, 20(2), 195-204.

Hulin, C. L., \& Smith, P. C. (1965). A linear model of job satisfaction. Journal of Applied Psychology, 49, 209-216.

Ismail, A., Ishak, M. S., Kuching, W., \& Omar, M. (2008). Hubungan sikap kepada wang dan kepuasan kerja terhadap keinginan pekerja untuk berhenti secara sukarela: Kajian di sebuah organisasi pihak berkuasa tempatan berstatus bandaraya di Sarawak. Jurnal e-Bangi, 3(3), 1-19.

Jaccard, J., Turrisi, R., \& Wan, C. K. (1990). Interaction effects in multiple regression. California: Sage Publications.

Judge, T. A. (1990). Job satisfaction as a reflection of disposition: Investigating the relationsip and its effect on employee adaptive behaviors (Unpublished Doctoral Dissertation). University of Illinois at Urbana-Champaign.

Judge, T. A. (1993). Does affective disposition moderate the relationship between job satisfaction and voluntary turnover? Journal of Applied Psychology, 78(3), 395-401.

Judge T. A., Thoresen C. J., Bono J. E., \& Patton G. K. (2001). The job satisfaction-job performance relationship: A qualitative and quantitative review. Psycholl Bull, 127(3), 376-407.

Kahneman, D., \& Tversky, A. (1979). Prospect theory: An analysis of decision under risk. Econometrica, 47, 263-291.

Kendall, L. M., Smith, P. C., Hulin, C. L., \& Locke, E. A. (1963). The relative validity of the Job Descriptive Index and other methods of measurement of job satisfaction. (Cornell Studies of Job Satisfaction: IV). Ithaca, NY: Cornell University, Industrial and Labor Relations.

IJMS 18 (1), 239-267 (2011) 263 
Lacity, M. C., Iyer, V. V., \& Rudramuniyaiah, P. S. (2008). Turnover intentions of Indian IS professionals. Information Systems Frontiers, 10 (2), 225-241.

Lawler, E. E. (1971). Pay and organizational effectiveness: A psychlogica view. New York: McGraw-Hill.

Leedy, P. D., \& Ormrod, J. E. (2005). Practical research: Planning and design. Upper Saddle River, N. J: Prentice Hall.

Linz, S. J. (2003). Job satisfaction among Russian workers. International Journal of Manpower, 24(6), 626-652.

Locke, E. A., Smith, P. C., Kendall, L. M., Hulin, C. L., \& Miller, A. M. (1964). Convergent and discriminant validity for areas and rating methods of job satisfaction. Journal of Applied Psychology, $48,313-319$.

McShane, S. L., \& Von Glinow, M. A. (2005). Organizational behavior. Boston: Mcgraw-Hill Irwin.

Milkovich, G. T., \& Newman, J. M. (2008). Compensation. Boston: McGraw-Hill Irwin.

Mobley, W. H. (1977). Intermediate linkages in the relationship between job satisfaction and employee turnover. Journal of Applied Psychology, 62(2), 237-240.

Mobley, W. H. (1982). Employee turnover: Causes, consequences, and control. Reading, MA:Addison-Wesley.

Mok, C., \& Finley, D. (1986). Job satisfaction and its relationship to demographics and turnover of hotel food-service workers in Hong Kong. International Journal of Hospitality Management, 5 (2), 71-78.

Motowidlo, S. J. (1983). Predicting sales turnover from pay satisfaction and expectation. Journal of Applied Psychology, 68(3), 484-489.

Mrayyan, M. T. (2007). Jordanian nurses' job satisfaction and intent to stay: Comparing teaching and non-teaching hospitals. Journal of Professional Nursing, 23(3), 125-136.

Nunally, J. C., \& Bernstein, I. H. (1994). Psychology theory. New York: McGraw-Hill.

Opsahl, R. L., \& Dunnette, M. D. (1966). The role of financial compensation in industrial motivation. Psychology Bulletin, 66, 94-118.

Park, J. S., \& Kim, T. H. (2009). Do types of organizational culture matter in nurse job satisfaction and turnover intention? Leadership in Health Services, 22(1), 20-38.

Randolph, D. S., \& Johnson, S. P. (2005). Predicting the effect of extrinsic and intrinsic job satisfaction factors on recruitment and retention of rehabilitation professionals. Journal of Healthcare Management, 50, 49-60. 
Sang, K. J. C., Ison, S. G., \& Dainty, A. R. J. (2009). The job satisfaction of UK architects and relationships with work-life balance and turnover intentions. Engineering, Construction and Architectural Management, 16(3), 288-300.

Sekaran, U. (2003). Research methods for business: A skill building approach. New York: John Wiley \& Sons.

Shields, M. A., \& Ward, M. (2001). Improving nurse retention in the National Health Service in England: The impact of job satisfaction on intentions to quit. Journal of Health Economics, 20(5), 677-701.

Smith, P. C., Kendall, L., \& Hulin, C. L. (1969). The measurement of satisfaction in work and retirement. Chicago: Rand McNally.

Schneider, B., \& Snyder, R. A. (1975). Some relationships between job satisfaction and organization climate. Journal of Applied Psychology, 60(3), 318-328.

Spector, P. (1997). Job satisfaction: Application, assessment, cause $\mathcal{E}$ consequences. London: Sage Publications.

Steers, R. M., Mowday, R. T. (1981). Employee turnover and postdecision accommodation processes. In L., Cummings \& B. Staw (Eds.), Research in organizational behavior (pp. 249-264). Greenwich, CT: JAI Press.

Tabachnick, B. G., Barbara, G., \& Fidell, L. S. (2001). Using multivariate statistics. Sydney: Allyn \& Bacon.

Tang, T. L. P. (1992). The meaning of money revisited. Journal of Organizational Behavior, 13(2), 197-202.

Tang, T. L.P. (1993). The meaning of money: Extension and exploration of the money ethic scale in a sample of university students in Taiwan. Journal of Organizational Behavior, 14, 93-99.

Tang, T. L. P. (1995). The development of a short money ethic scale: Attitudes toward money and pay satisfaction revisited. Personality and Individual Differences, 19, 809-816.

Tang, T. L. P. (2007). Income and quality of life: Does the love of money make a difference? Journal of Business Ethics, 72, 375-393.

Tang, T. L. P., \& Baumeister, R. F. (1984). Effects of personal values, perceived surveillance, and task labels on task preference: The ideology of turning play into work. Journal of Applied Psychology, 69(1), 99-105.

Tang, T. L. P., Furnham, A., \& Davis, G. M. (2002a). The meaning of money: The money ethic endorsement and work-related attitudes in Taiwan, the USA and the UK. Journal of Managerial Psychology, 17(7), 542-563.

Tang, T. L. P., \& Gilbert, P. R. (1995). Attitudes toward money as related to intrinsic and extrinsic job satisfaction, stress, and work related attitudes. Personality and Individual Difference, 19, 327-332.

IJMS 18 (1), 239-267 (2011) 265 
Tang, T. L. P., \& Kim, J. K. (1999). The meaning of money among mental health workers: The endorsement of money ethic as related to organizational citizenship behavior, job satisfaction, and commitment. Public Personnel Management, 28(1), 15-26.

Tang, T. L. P., Kim, J. K., \& Tang, D. S. H. (2000). Does attitude toward money moderate the relationship between intrinsic job satisfaction and voluntary turnover? Human Relations, 53(2), 213-245.

Tang, T. L. P., Kim, J. K., \& Tang, T. L. (2002b). Endorsement of the money ethic, income, and life satisfaction: A comparison of full-time employees, part-time employees, and non-employed university student. Journal of Managerial Psychology, 17(6), 442467.

Tang, T. L. P., Luna-Arocas, R., Sutarso, T., \& Tang, D. S. H. (2004a). Does the love of money moderate and mediate the income-pay satisfaction relationship? Journal of Management Psychology, 19(2), 111-135.

Tang, T. L. P., Tillery, K. R., Lazarevski, B., \& Luna-Arocas, R. (2004b). The love of money and work-related attitudes: Money profiles in Macedonia. Journal of Managerial Psychology, 19(5), 542-548.

Udechukwu, I. I. (2007). The influence of intrinsic and extrinsic satisfaction on organizational exit (voluntary turnover): Evidence from a correctional setting. Journal of Applied Management and Entrepreneurship, 12(1), 127-142.

Usunier, J. C. (1998). International and cross-cultural management research. London: Sage Publications.

van Dam, K. (2008). Time frames for leaving: An explorative study of employees' intentions to leave the organization in the future. Career Development International, 13(6), 560-571

Vidal, E. S., Valle, R. S., \& Aragon, I. B. (2007). Antecedents of repatriates' job satisfaction and its influence on turnover intentions: Evidence from Spanish repatriated managers. Journal of Business Research, 60(912), 1272-1281.

Weiss, H. M. (2002). Deconstructing job satisfaction: Separating evaluations, beliefs and affective experiences. Human Resource Management Review, 12, 173-194.

Wernimont, P. F. (1966). Intrinsic and extrinsic factors in job satisfaction. Journal of Applied Psychology, 50, 41-50.

Wright, L. L. (1996). Qualitative international management research. In B.J. Punnett \& O. Shenkar (Eds.), Handbook for international management research (pp. 63-81). Oxford; UK: Blackwell Publishers. 
Wu, L., \& Norman, I. J. (2006). An investigation of job satisfaction, organizational commitment and role conflict and ambiguity in a sample of Chinese undergraduate nursing students. Nurse Education Today, 26(4), 304-314.

Yamauchi, K. T., \& Templer, D. I. (1982). The development of a money attitude scale. Journal of Personality Assessment, 46, 522-528. 